\title{
Investigation and Analysis on the Current Situation of Free Combat Optional Course of General Colleges in Liaoning Province
}

\author{
Guan Shuo \\ Wushu Department \\ Shenyang Sport University \\ Shenyang, China \\ shenyangtaixie@163.com
}

\begin{abstract}
It has positive auxo-action on the quality-oriented education and lifelong physical training of modern undergraduates to develop the sports of martial art and free combat in regular institutions of higher learning. In this article we adopt the questionnaire survey method to conduct a survey on the current situation of free combat optional course in five general colleges in Liaoning Province, analyze and discuss the existing problems while teaching and then put forward constructive suggestions. In this article we mainly conduct survey and research on the teaching staffs, students, teaching content and playing field equipments, etc, know and understand the current situation of general college students participating in the sport of free combat, and analysis the factors that affect their choice of free combat optional course in order to give proposals and countermeasures for the transformation of education and promoting the development of Wushu Sport in regular institutions of higher learning.
\end{abstract}

Key words-general colleges in Liaoning Province; free combat optional course; current situation survey; analysis

\section{INTRODUCTION}

As a kind of excellent national traditional forms of physical training, Chinese $\mathrm{Wu}$ Shu has its own deep traditional culture connotation and special style of sports arts, it is the synthesis which has integrated fitness, entertainment and military skills. Wushu, the quintessence of our country, is a high-level culture which belongs to sports but higher than sports. As a major form of motion of Wushu, free combat sport is a maximized embodiment of its art of attack and defense. Free combat sports is a new modern competitive sporting event and embodies the traditional Wushu in modern society, it has developed on the basis of traditional Wushu, and tried to find a new competitive form to reflect the practical value of art of attack and defense of Wushu directly, it also has the same characteristics of simple and useful as the modern fighting event, and has certain opposability and ornamental value.

The characteristics of art of attack and offense, competitiveness and cultural make free combat sports become more and more popular among college students, as the innovation of college physical education constantly goes deeper, establishing free combat optional course in colleges may not only enrich teaching content, meet the physical and mental needs of undergraduates, fully embody the educational concept of "people oriented", but also plays a decisive role in inheriting and developing traditional culture, spreading the spirit of Wushu and promoting the popularization of free combat sports. In this article we try to know the current situation of undergraduates' free combat optional course so as to find the restraining factor of free combat sports development and find out the countermeasures by conducting investigation on the number, motivation, learning state, teaching content, quality of teachers and playing field equipments of the students in five general colleges in Liaoning Province, in order to provide beneficial reference for school physical education innovation and the popularization and development of free combat sports.

The free combat course of part colleges of Liaoning was established in recent years, therefore, it is very necessary to conduct a serious investigation on the current situation of free combat course in universities and colleges of Liaoning Province, analyze the current situation and then put forward countermeasures for the problems in current situation. Meanwhile, it may provide reference for the further innovation and development of free combat course in universities and colleges of Liaoning Province.

\section{OBJect AND Method of RESEARCH}

\section{A. Object of Research}

Take the current situation of free combat optional course in next semester of 2012 of Liaoning Normal University, Dalian University of Technology, Liaoning University of Technology, University of Science and Technology Liaoning, Shenyang Normal University as object of research.

\section{B. Research Method}

1) Literature consultation method

Consult and collect document literature about course reform, higher education, works, literatures and documents in the field of teaching as well as course outline of free combat optional course in the institutions of higher learning, etc. of recent years, and search related knowledge on the CJN.

\section{2) Questionnaire survey method}

Conduct questionnaire survey on the students who has chosen free combat optional course in next semester of 2012 of Liaoning Normal University, Dalian University of Technology, Liaoning University of Technology, University 
of Science and Technology Liaoning, Shenyang Normal University, we have issued in total 200 questionnaires, among that 196 were effective, the effective rate has reached to $98 \%$, which meet the needs of social investigation.

\section{3) Mathematical statistics method}

Know and analyze related knowledge and problems, and take reasonable reasoning on the statistic results.

\section{RESULTS AND ANALYSIS}

\section{A.The survey of free combat optional course of general} colleges in Liaoning province

1) Understanding of free combat of students in general college of Liaoning Province

It is shown from Table 1 that the number of students who know free combat very well accounts for $10 \%$, the number of students who are familiar with free combat accounts for $25 \%$, the number of students who know of free combat accounts for $37.5 \%$, the number of students who don't know free combat at all accounts for $27.5 \%$, therefore students of general colleges in Liaoning Province know a little about of free combat which means the popularization of free combat is lower in colleges, it is one of main tasks of colleges.

Table 1 Awareness of free combat of general college students in Liaoning Province

\begin{tabular}{lcc}
\hline knowledge & number & Percentage \\
Know very well & 20 & $10 \%$ \\
Be familiar with & 50 & $25 \%$ \\
Know of & 75 & $37.5 \%$ \\
Do not know at all & 55 & $27.5 \%$ \\
\hline
\end{tabular}

2) Survey on cognition channels of free combat of general college students in Liaoning Province

Learning about students' cognition channels of free combat is helpful to figure out their basic cognitive background. Table 2 shows us: firstly, majority students attending free combat course lack of base knowledge. Most of them know about free combat from television and film or books about martial arts, and know a little about concept and skills of it, indicating movies and television have a great effect on basic cognition of free combat of young college students. Secondly, viewed from martial arts teaching channels of colleges, in which actual martial arts teaching exists, we can find college students acquire basic understanding about martial arts under the premise of paying attention to entertainment, and free combat is not a sport drawing active attention from young people. Thirdly, it is a quite small part of students who learn about free combat from martial art fictions, part exercises, free combat club and professional martial art books, which suggests martial art fictions have a limited impact on young students. There is less time for them to study free combat in a part or to read professional martial art books.
Table 2 Cognition channels of free combat of general college students in Liaoning Province

\begin{tabular}{lc}
\hline \multicolumn{1}{c}{ Options } & Ranking \\
\hline Action Movies & 1 \\
Class teaching in PE course & 2 \\
Living free combat match & 3 \\
Friends attending free combat study & 4 \\
Family teaching & 9 \\
Free combat club & 10 \\
Public free combat contact & 5 \\
News papers & 7 \\
None & 8 \\
Professional martial art books & 6 \\
\hline
\end{tabular}

3) Investigation on motivation of choosing free combat optional course of general colleges students in Liaoning Province

The investigation on motivation of students' participating in study of free combat course is mainly specific to students who have already finished their study of free combat course. Table 3 indicates that $25 \%$ of the students conduct free combat study with keen interest, which is extremely important for further carrying out of free combat teaching of general colleges, and teachers should positively take use of it to develop free combat education. There are also $55 \%$ of the students who learn about from students, who attended relevant study before, that teacher of free combat optional course doesn't require strictly and it is easy to pass the exam and obtain credits required by graduation. Part female students and some others with weak constitution choose this course because of low activity level and intensity and easy passing exam.

Table 3 Motivation of choosing free combat course of general colleges students in Liaoning Province

\begin{tabular}{lll}
\hline $\begin{array}{l}\text { Options } \\
\text { Percentage (\%) }\end{array}$ & Number of People (n) \\
\hline With keen interest & 50 & $25 \%$ \\
Easy to obtain credits & 40 & $20 \%$ \\
Relaxed requirements & & \\
from teacher & 70 & $35 \%$ \\
Low activity level and intensity & 40 & $20 \%$ \\
\hline
\end{tabular}

B. Investigate on teacher situation of Liaoning general colleges

1) Investigate on free combat optional course teachers' age structure of Liaoning general colleges

Age structure means the proportional relationship of number of people in each age group of a social group. The teachers' age structure can decide and reflect the creativity of a talent group in a certain extent. Free combat teaching quality of general colleges mainly depends on the teachers' professional skill, specialized quality, age, educational degree, etc. Just a high-quality free combat teacher team with high professional technical level, profound specialized 
knowledge and energy can cultivate students' learning interest when implementing free combat teaching, attract more people to join in and identify this sport, and promote the positive development of free combat in colleges. Table 4 shows that there are 9 teachers under the age of 30 years old which occupy 36\%; there are 13 teachers between 31 years old to 40 years old which occupy 52\%; there are 2 teachers between 41 years old to 50 years old which occupy $8 \%$; there is 1 teacher over the age of 50 years old which occupies 4\%. Free combat teachers' age distribution of Liaoning general colleges is good for inheriting aged teachers' teaching experience, younger teachers' development according to times and unceasing innovation to items, which can basically meet students' learning demand.

Table 4- Investigate on free combat optional course teachers' age structure of Liaoning general colleges

\begin{tabular}{lll}
\hline Age & Number (n) & Percent (\%) \\
\hline $\begin{array}{l}\text { Under the age of } 30 \text { years } \\
\text { old }\end{array}$ & 9 & $36 \%$ \\
$\begin{array}{l}\text { Between } 31 \text { years old to } \\
40 \text { years old }\end{array}$ & $52 \%$ \\
$\begin{array}{l}\text { Between } 41 \text { years old to } \\
50 \text { years old }\end{array}$ & 2 & $8 \%$ \\
\hline $\begin{array}{l}\text { Over the age of } 50 \text { years } \\
\text { old }\end{array}$ & 1 & $4 \%$ \\
\hline
\end{tabular}

2) Investigate on free combat optional course teachers' educational degree of Liaoning general colleges

Table 5- Investigate on free combat optional course teachers' educational degree of Liaoning general colleges

\begin{tabular}{lll}
\hline Educational Degree & Number (n) & Percent (\%) \\
\hline Doctor & 0 & $0 \%$ \\
Master & 9 & $68 \%$ \\
Bachelor & 16 & $32 \%$ \\
\hline $\begin{array}{l}\text { Graduated form } \\
\text { junior college }\end{array}$ & 0 & $0 \%$ \\
\hline
\end{tabular}

Educational degree structure means the structure of teacher's final educational degree. Educational degree represents the degree of normal education someone received, and educational degree structure reflects the culture quality of the teacher team. Table 5 shows that there is no teacher with degree of doctor; there are 9 teachers with degree of master which occupy 32\%; there are 16 teachers with degree of bachelor which occupy 68\%; there is no teacher who graduated from junior college. Table 5 shows that most of teachers have the degree of bachelor, which means the free combat teachers of Liaoning general colleges have relatively high educational degree. Most of free combat teachers with Bachelor Degree or higher have relevant specialized knowledge and quality to meet students' requirement to learn free combat, which is good for spreading and improving the development of free combat in Liaoning general colleges.

3) Investigate on free combat optional course teachers' specialty of Liaoning general colleges

Table 6 Investigate on free combat optional course teachers' specialty of Liaoning general colleges

\begin{tabular}{lll}
\hline Specialty & Number (n) & Percent (\%) \\
\hline Free combat & 8 & $32 \%$ \\
Routine & 15 & $60 \%$ \\
\hline Others & 2 & $8 \%$ \\
\hline
\end{tabular}

Table 6 shows that there are 8 teachers whose specialty is free combat which occupy $32 \%$; there are 15 teachers whose specialty is routine which occupy $60 \%$; there are 2 teachers have other specialties which occupy $8 \%$. Proportion of teacher in Liaoning general colleges is unreasonable. Proportion of Wushu and free combat teachers in Liaoning general colleges is small. Serious shortage exists.

4) Students' evaluation to free combat optional course teachers in Liaoning general colleges

Table 7 students' evaluation to free combat optional course teachers in Liaoning general colleges

\begin{tabular}{|c|c|c|c|c|c|}
\hline Item & Excellent & Preferable & So-so & Bad & Total \\
\hline $\begin{array}{l}\text { Teaching } \\
\text { Attitude }\end{array}$ & $20.4 \%$ & $27.8 \%$ & $46.7 \%$ & $5.1 \%$ & $100 \%$ \\
\hline $\begin{array}{l}\text { Demonstrating } \\
\text { Ability }\end{array}$ & $18.6 \%$ & $26.9 \%$ & $47.3 \%$ & $7.2 \%$ & $100 \%$ \\
\hline $\begin{array}{l}\text { Language } \\
\text { Expression }\end{array}$ & $14.8 \%$ & $21.1 \%$ & $51.3 \%$ & $12.8 \%$ & $100 \%$ \\
\hline $\begin{array}{l}\text { Teaching } \\
\text { Innovation } \\
\text { Ability }\end{array}$ & $13.5 \%$ & $19.6 \%$ & $54.6 \%$ & $12.35 \%$ & $100 \%$ \\
\hline
\end{tabular}

Table 7 shows that almost half of students deem free combat teachers' teaching attitude is only so-so. In any teaching process, if teachers who play a leading role do not have good attitude and are perfunctory to leaders and students can never mobilize students' enthusiasm or ensure teaching quality. Only $45.5 \%$ of students, most of them are not students of P.E. department of normal colleges, deem the teachers' demonstrating ability is excellent. $12.8 \%$ of students deem teachers' language expression is too general and unclear, but these students deem the teachers have pretty good demonstrating ability. Investigate on contents of free combat course in Liaoning general colleges

Table 8 shows that contents of free combat course in Liaoning general colleges are mainly basic standing posture, fist position and footwork, leg technique and occasionally physical quality exercise and combination exercise. Attacking and defending technique is a small fraction. No actual combat exercise is arranged.

Table 8 Investigate on content of course of free combat in Liaoning general colleges

\begin{tabular}{|c|c|c|}
\hline Contents & $\begin{array}{l}\text { Number } \\
\text { (n) }\end{array}$ & $\begin{array}{l}\text { Percent } \\
(\%)\end{array}$ \\
\hline $\begin{array}{lll}\text { Basic standing } & \begin{array}{r}\text { posture, } \\
\text { position and }\end{array} \\
\text { technique } & \text { footwork, } & \text { leg }\end{array}$ & 87 & 92.5 \\
\hline Physical quality training & 16 & 17 \\
\hline Combination exercise & 18 & 19.1 \\
\hline $\begin{array}{l}\text { Attacking and defending } \\
\text { technique }\end{array}$ & 7 & 7.4 \\
\hline Actual combat exercise & 0 & 0 \\
\hline
\end{tabular}




\begin{abstract}
Referee technique 5 5.3

5) Investigate on grounds and facilities of free combat optional course teachers in Liaoning general colleges

The result of investigation on 5 Liaoning colleges which offer Wushu and free combat course shows that there are just 2 colleges have specialized indoor grounds for Wushu and free combat course. In other colleges, free combat course have to share one ground with basketball class, volleyball class and ping-pang class. What's worse, these colleges are seriously lack of facilities for Wushu and free combat like boxing glove, sandbag, head protection, flak jacket and jockstrap. Shortage of grounds and facilities limits the development of Wushu and free combat of colleges.

Grounds and facilities are the material basis and guarantee to improve teaching quality and complete teaching mission. It is hard to ensure teaching quality of large-scale collective teaching without grounds or facilities. The investigation shows that $22.5 \%$ of Liaoning general colleges only can use grounds and facilities for classes; $48 \%$ of colleges are lack of grounds and facilities, and contention for grounds and facilities happens occasionally; $19.5 \%$ of colleges are seriously lack of grounds and facilities; just $8 \%$ of colleges have enough grounds and facilities.
\end{abstract}

\section{IV.CONCLUSIONS AND SUGGESTIONS}

\section{A.Conclusions}

1)Students in Liaoning general colleges have little knowledge of free combat, which shows that the free combat is not very popular; free combat has not become the sport which can be leant by younger people actively; the teaching objectives of free combat have not been fully realized.

2)Now, educational degree of free combat teachers in Liaoning general colleges is relatively low. The scientific researching ability has yet to be improved, and distribution of specialties is unreasonable.

3)Students deem teachers' attitude, teaching organization and method have yet to be improved.

4)Most of students deem contents of free combat optional course are boring. The teaching contents mainly focus on the most basic content, and there are too few attacking and defending technique, actual combat exercise and referee technique. The single teaching content leads to inactive classroom atmosphere and students' negative learning attitude.

5) Liaoning general college students' main motivation to select free combat class is to gain credits easily. The teachers don't have strict requirement to students, and it is very easy to pass examination. There are still some female students and the students whose physical quality is not good select free combat for less activity and exercise intensity and examination easy to pass.

6) In most Liaoning general colleges, free combat optional course share grounds with basketball course, volleyball course and athletics course, and very few colleges have specialized classrooms for free combat. Free combat facilities are not perfect, and necessary protective clothing is lacked during teaching process.

\section{B.Suggestions}

1) Liaoning general colleges shall import professional teachers and improve training for working free combat teachers by preferential policies and provide enough opportunities for teacher to improve their professional skill, and thus the solid foundation for development and scientific research of Liaoning general colleges can be built.

2)Perfect subject construction which includes elective system, teaching plan. Break the traditional mode and let students join in the curriculum provision to achieve the knowledge they really want and form the habit of life-long physical exercise.

3)Colleges shall increase the investment on the physical infrastructures further, such as grounds, facilities, modern teaching attachments, etc, to create a good environment to develop free combat sports in colleges.

4) Free combat teachers of colleges shall pay more attention to perfect teaching content, improve teaching skill and enhance students' learning interest. Meaning while, teachers shall actively guide students' leisure activity of free combat and build good interactive system both in and out of class.

5) Perfect existing examination system; comprehensively consider students' learning foundation and degree of efforts to realize humanism examination system and ensure the transformation of free combat teaching to quality-ordered education.

\section{REFERENCES}

[1] Deng Yongming. The Teaching and Reform Suggestion in optional course of Wushu in Colleges [J]. Journal of Shandong Sports University

[2] Shao Xia. Research and Exploration on Development of Wushu and Free Combat in General Colleges [J]. Journal of Xianning University, 2010, 30 (9): 124-125

[3] Shen Guoqing. Analyze the Psychological Factor of Free Combat Teaching in General Colleges [J]. Journal of Physical Education Institute of Shanxi Teachers University, 2005, 20 (1): 102-104.

[4] Ruan Sheng. Discuss of the Current Situation and Development of Free Combat [J]. Journal of Wuhan Institute of Physical Education, 2005, 39 (6): 78-80

[5] Yue Qingli. Research and Investigation on Wushu Cognition of Amateur Wushu College Students [J] Journal of Beijing Sport University, 2005, 28 (7): 1003-1006 